\title{
VÝZNAM ŠKOLNÍCH SESTER/MENTOREK PRO ZAJIŠTĚNÍ KVALITY VÝUKY NA KLINICKÝCH PRACOVIŠTÍCH
}

\section{Hana Sloupová-Bürgerová, Andrea Hudáčková}

Jihočeská univerzita v Českých Budějovicích, Zdravotně sociální fakulta, katedra ošetřovatelství

\section{ÚVOD}

Hlavním cílem katedry ošetřovatelství je zajišt'ovat kvalitní výuku jak $\mathrm{v}$ teoretické, tak i v praktické části vzdělávání studentů. Dosavadní průběh praktické výuky měli v kompetenci výhradně odborní asistenti katedry. Tento trend bude postupně vystř́dán vedením praktické výuky školními sestrami/mentorkami, resp. sestrami z klinických pracovišt'.

$\mathrm{V}$ akademickém roce 2001 byl na Zdravotně sociální fakultě Jihočeské univerzity v Českých Budějovicích reakreditován bakalářský studijní program Ošetřovatelství. Jeho dnešní podoba respektuje evropskou strategii Světové zdravotnické organizace pro vzdělávání tzv. regulovaných nelékařských profesí (všeobecných sester a porodních asistentek) z roku 1998 a př́slušná direktiva Evropské komise a jejich doporučení (Tóthová, 2002).

Studijní program Ošetrovatelství je členěn na obor Všeobecná sestra a obor Porodní asistentka. Studenti získávají způsobilost $\mathrm{k}$ výkonu povolání bez odborného dohledu kvalifikačním studiem dle zákona č. 93/2004 Sb., o nelékařských profesích, který je v souladu se směrnicemi Evropské unie.

Zdravotní sestry a porodní asistentky jsou připravovány na výkon praxe ve světě, kde se znalosti neustále rozvijejí. Didaktické přednášky poskytují potřebné vědomosti. $\mathrm{V}$ teoretické př́pravě studentů $\mathrm{v}$ rámci seminářů je proto směřováno ke zprostř̌edkování takových vzdělávacích zkušeností, kdy se studenti naučí, jak se učit nejen z učebnic. Důraz je též kladen na interakci ve skupinách, tak aby byli $\mathrm{v}$ praxi způsobilí jak pro autonomní práci, tak práci v týmu. Již v žádném prrípadě nejde o předkládání statických souborů faktů. Role studenta již není pasivní. Student se musí aktivně účastnit studia a musí být veden $\mathrm{k}$ tomu, aby zvažoval jednotlivé možnosti, prakticky si vyzkoušel a využil to, čemu se na vysoké škole učí.

Mezi hlavní předměty během profesní přípravy všeobecných sester a porodních asistentek bezesporu patř́ teorie a odborná praxe. $\mathrm{V}$ teoretické př́pravě studentů $\mathrm{v}$ rámci seminářu je proto směřováno ke zprostředkování takových vzdělávacích zkušeností, aby se studenti naučili učit se nejen z učebnic (Strategické dokumenty, 2002).

Pro praktickou výuku studenti získávají potřebné vědomosti nejprve nácvikem $\mathrm{v}$ odborných učebnách (laboratořích), které jsou průběžně dovybavovány nejnovějším zdravotnickým materiálem a technikou. Přesto je profesní př́prava sester a porodních asistentek na vysokých školách $\mathrm{v}$ České republice stále $\mathrm{v}$ počátcích (Salvage, 1997).

Hlavním cílem do budoucna je zajistit kvalitní výuku jak v teoretické, tak i v praktické části vzdělávání studentů. Dosavadní průběh praktické výuky na ZSF JU měli v kompetenci výhradně odborní asistenti katedry ošetřovatelství. Tento trend bude postupně vystřídán vedením praktické výuky školními sestrami/mentorkami, resp. sestrami z klinických pracovišt'.

Doposud nebylo legislativou ani jinou direktivou v ĆR stanoveno, zda terminologicky označovat sestry z klinických pracovišt' školními sestrami - tento výraz je spíše vhodný pro středoškolský typ vzdělávání. Nebo využívat pojem mentor/ mentorka, jehož definice dle Youth Justice Board zní: „Mentor je osoba, která pomáhá ostatním dosáhnout svého potenciálu. Jeho role zahrnuje koučování, povzbuzování, konstruktivní kritiku, vysvětlování, naslouchání a vedení. Základem mentorování je vztah mezi dvěma osobami, kdy jedna pomáhá té druhé dosáhnout svých cílư““. $\mathrm{V}$ anglické terminologii též existuje výraz tutor, který může být $\mathrm{v}$ určitých prrípadech (převážně u kombinované a distanční formy studia) považován za synonymum. $\mathrm{V}$ oblasti studijního oboru Ošetřovatelství je prioritou, aby mentoři vedli studenty důkladně, tak aby v posledním roce studia byli schopni přebrat odpovědnost za celkovou péči o nemocného, příp. skupinu nemocných.

Nedílnou součástí a podstatným prvkem mentorství v rámci dosahování cílů studentů je validní, spolehlivé, především průběžné hodnocení studentů, které by mělo směřovat $\mathrm{k}$ cenné zpětné vazbě, která odrazí činnosti prováděné během praxe.

Ze zkušenosti víme, že způsobem adekvátního vedení praxe formou mentorství lze zajistit stabil- 
ně kvalitní vzdělávání studentů. Hledání kvality je proces, který nekončí, je průběžný, ale neměl by být vnímán jako hledání chyb a kazů, ale jako hledání př́tomnosti hodnot a způsobů, jak tyto hodnoty ještě navýšit.

V lednu 2005 byla v souvislosti s tímto tvrzením provedena pilotní studie, které se zúčastnilo celkem 29 sester z klinické praxe a 46 studentů studijního oboru všeobecná sestra. Z výsledků studie mimo jiné vyplývá, že přestože odborní asistenti jsou pozitivně vnímáni u více než $30 \%$ studentů a přibližně u poloviny dotazovaných z řad sester, současnou snahu katedry ošetřovatelství převést část kompetencí $\mathrm{v}$ rámci praktické výuky na mentory by uvítalo $97 \%$ studentů a 76 $\%$ sester z klinických pracovišt'.

Význam školních sester/mentorek pro zajištění kvality výuky na klinických pracovištích je neznepochybnitelný. Pro studenty je přínosem, mohou-li pracovat pod dohledem odborného pracovníka, který je jim $\mathrm{k}$ dispozici podle potřeby při poskytování péče klientům, ale i v prŕpadě řešení nových situací potřebných pro budoucí profesní život. Z tohoto faktu můžeme usuzovat i na přínos pro vlastní klinické pracoviště, kde školní sestra/mentor pracuje, protože nedochází $\mathrm{k}$ přetížení ostatního zdravotnického personálu v souvislosti s dotazy a kontrolou studentů. Funguje-li tato kooperace, mohou odborní asistenti věnovat více času efektivní spolupráci ve vztahu klinické pracoviště - student - fakulta, přičemž mentorky zajišt'ují komunikaci v rovině student sestry. Jsou-li studenti vedeni sestrami $z$ praxe, mohou být lépe uspokojeny jejich individuální požadavky v oblasti plánování harmonogramu práce. Studenti mohou pracovat dle svých schopností a jejich rozvoj může být dynamičtější, pokud mají $\mathrm{k}$ dispozici stávajícího člena ošetřovatelského týmu, který je dobře orientovaný $\mathrm{v}$ chodu a specifikách daného oddělení. Předpokladem kvalitního vedení studentů je práce $\mathrm{v}$ ošetřovatelském procesu a postup dle standardů.

Již nyní katedra ošetřovatelství připravuje podmínky pro aplikaci této vize. Školní sestry jsou systematicky pripravovány na svou novou roli. Konečným výstupem snahy má být efektivní odborná praktická výuka a její kvalitní vedení sestrami.

Boloňská deklarace z r. 1999 zdůrazňuje potřebu hodnocení kvality výuky. Z tohoto doporučení vychází i dosavadní interní a externí hodnocení, na základě něhož dochází v teoretické části výuky $\mathrm{k}$ úpravám sylabů, změnám studijní literatury, inovacím cvičení a seminářù.

Snahou katedry ošetřovatelství do budoucna je, aby poznatky z hodnocení kvality výuky v teoretické oblasti aplikovala i do odborné praktické výuky.

\section{LITERATURA}

http://www.vutbr.cz/to.cs/vvztahy/bologna.php Ministerstvo zdravotnictví ČR 2002: Strategické dokumenty pro všeobecné sestry a porodní asistenty II. Praha.

Salvage, J. 1997: Ošetřovatelství v akci. Přel. A. Strajtová. Vydala: Česká společnost sester, $119 \mathrm{~s}$. Přel. z: Nursing in action. ISBN 9289013125

Tóthová, V. 2002: Profesní príprava sester a porodních asistentek na Zdravotně sociální fakultě Jihočeské univerzity. In: Kontakt 4 (4); České Budějovice: Zdravotně sociální fakulta Jihočeské univerzity v Českých Budějovicích, s. 196 - 199. ISSN 1212-4117.

Hana Sloupová-Bürgerová, sloupova@zsf.jcu.cz Andrea Hudáčková,hudaca@zsf.jcu.cz 